\title{
Globalizing the Harlem Renaissance: Irish, Mexican, and 'Negro' renaissances in The Survey, 1919-1929
}

\author{
Bob Johnson \\ Department of Social Sciences, New College of Florida, 5700 North Tamiami Trail, \\ Sarasota, FL 34243, USA \\ E-mail: rjohnson@ncf.edu
}

\begin{abstract}
This essay situates the Harlem Renaissance in a world-historical context by building on the global perspective offered by the architect of that renaissance, Alain Locke. It demonstrates that contemporaries like Locke saw the Harlem Renaissance to be a local episode in a broader phenomenon of racial and national renaissance that included post-war developments in Ireland and Mexico. The core argument is that American progressives found in these renaissances three distinct models for defining the proper relationship between race and nation: in the Irish case, a racially homogeneous nation-state premised on a repudiation of the colonizer and his culture; in the Mexican case, a syncretic nation-state based on the cultural and biological fusion of the colonizer and colonized; and in the Harlem case, a pluralist nationstate that held in balance otherwise relatively autonomous races.
\end{abstract}

\section{Introduction}

The 'Negro Renaissance' that followed the First World War took shape within a worldhistorical context. It was, as contemporaries understood, a local instance in a broader set of national and racial awakenings of subject peoples across the post-war globe. The dean of that renaissance, Alain Locke, said as much in 1925 in his opening remarks to The new negro anthology. In the introduction to that canonical text, a work typically recognized to be the bible of the Harlem Renaissance, Locke connected the 'resurgence of a people' in Harlem, New York to developments occurring across the world, 'in India, in China, in Egypt, Ireland, Russia, Bohemia, Palestine, and Mexico'. He explained that like Europe which was 'seething in a dozen centers with emergent nationalities' and Palestine which was 'full of a renascent Judaism', Harlem was part of a pattern in world events, one among several 'nascent movements of... self-determination...playing a part in the world to-day'. ${ }^{1}$

1 Alain Locke, The new negro, New York: Simon and Schuster, 1992, pp. xxvii-7. 
By placing the Harlem Renaissance 'in the perspective of' this emerging new world, Locke gave to it a world-historical orientation. His words remind us that that event took shape in a remarkable period that included the birth of communism in Russia, the May 4th uprising in China, the emergence of fascism in Italy, the advent of a new Ireland in northern Europe, the quickening of Zionism throughout the West and near East, and the dawn of a new Mexico in Latin America. In framing the Harlem Renaissance in such a way, Locke invited his contemporaries to regard it as an episode in a global phenomenon of racial and national renaissance. ${ }^{2}$

Alain Locke was not alone in viewing the Harlem Renaissance in such a way. Other American progressives of the time also perceived it to be a local expression of larger global forces. As the historian Alan Dawley has recently observed, many progressives like Locke viewed the post-war world itself as a world in flux in which great social movements were recasting international relations and remaking modern peoples. Such progressives, he reminds us, were no provincials; theirs was a vibrant, multicultural world, alive with 'African rhythms, Indian ragas, Chinese folk tunes, and the "Communist Internationale", ,3 Of course, it would be overstating the case to say that all post-war progressives viewed the events in Harlem in such an openly cosmopolitan fashion, but it was precisely in these years that a critical segment of the American progressive community took important steps towards adopting the type of pluralist discourse on global relations with which today's progressives are more than a little familiar.

Such an orientation was nowhere more clearly developed than in the pages of the journal that introduced the New Negro and the Harlem Renaissance to a national audience, The Survey. From its inception in 1909 until its discontinuation in 1952, The Survey, along with its illustrated monthly edition, Survey Graphic, forged an internationalist discourse with a decidedly pluralist bent. Even if its audience was limited to a small core of social reformers, academics, missionaries, and bureaucrats who comprised the progressive coalition in these years, The Survey was no minor affair either intellectually or politically. Jane Addams, Gifford Pinchot, John Commons, John Collier, Stella Atwood, Mary Austin, Robert Park, Lewis Hine, Robert La Follette - all figures affiliated with The Survey in one form or another - comprise a who's who of early twentieth-century American progressivism, giving the magazine a representativeness that few other publications can match. ${ }^{4}$

As historians of the New Negro movement have long known, The Survey played a key role in institutionalizing the Harlem Renaissance, its 1 March 1925 issue - 'Harlem: Mecca of the new negro' - functioning as something of a landmark text in the construction of that renaissance. ${ }^{5}$ It was in this issue of the magazine that Locke, in collaboration with The Survey's editors, proclaimed the birth of a New Negro and conscripted the pre-eminent African-American writers, intellectuals, and artists of the time into his version of a 'Negro

2 Ibid.

3 Alan Dawley, Changing the world: American progressives in war and revolution, Princeton, NJ: Princeton, 2003, p. 220.

4 For more information on The Survey, see Clarke Chambers, Paul Kellogg and The Survey; voices for social welfare and social justice, Minneapolis, MN: University of Minnesota, 1971.

5 George Hutchinson, The Harlem Renaissance in black and white, Cambridge, MA: Harvard University Press, 1995; David Levering Lewis, When Harlem was in vogue, New York: Penguin, 1997; and Nathan Huggins, Harlem Renaissance, New York: Oxford University Press, 1971. 
Figure 1. Cover, 'Harlem: Mecca of the new negro', Survey Graphic, March 1925

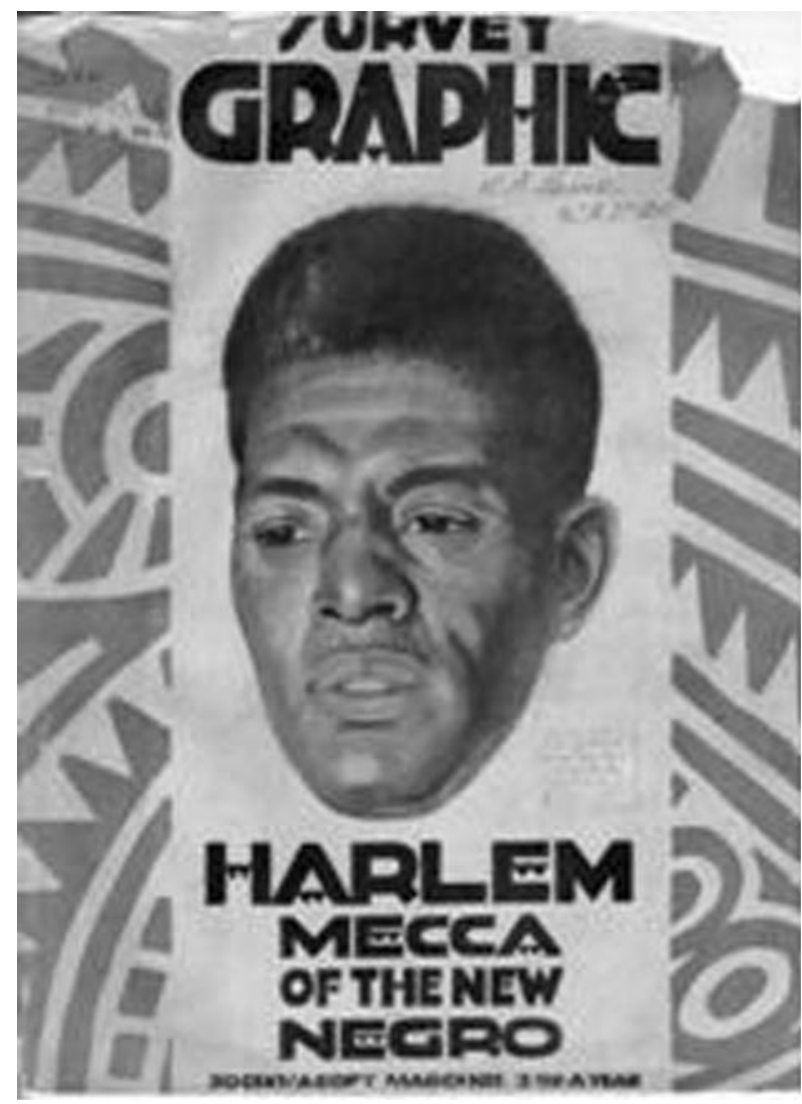

Renaissance'. This one volume contained the work of major figures like Langston Hughes, Jean Toomer, Countee Cullen, W. E. B. Dubois, Angelina Grimke, and Claude McKay, and as importantly, the articles, poems, and editorials that comprised the issue became the basis of the aforementioned The new negro anthology published the following year. Locke's pronouncement of a 'Negro Renaissance' in these works depended, of course, on an intellectual and political foundation that had been previously built by other African Americans, but the idea that a 'renaissance' was in the air awaited the type of institutional focus provided by 'Harlem: Mecca of the new negro' (Figure 1).

The global context of the Harlem Renaissance becomes especially clear when we examine the literary context in which 'Harlem: Mecca of the new negro' was published. That path-breaking issue was part of an annual series of what The Survey staff termed its 'Race Issues', a series that had begun several years before the publication of the Harlem number and one that continued for several years afterwards. Progressives introduced to the Harlem Renaissance in The Survey read in other issues about the resurgence of the Irish and the new Ireland; the building of a new Russian identity in Soviet Russia; the birth of fascism in Italy; the struggle for Pueblo self-determination in the American Southwest; the rebirth of a Mexican people in post-revolutionary Mexico; and the transformation of 
'Oriental' identities throughout the Pacific Rim. ${ }^{6}$ Bound together by the metaphor of racial/ national awakening, The Survey's race series explicitly located the Harlem Renaissance within an historical moment characterized by concurrent struggles to document, define, and remake the world's races and nations. ${ }^{7}$

This essay makes the case that recovering the progressive meta-narrative articulated by Locke adds an international dimension to the Harlem Renaissance that complements current transnational scholarship concerned with the pan-African features of that renaissance, while it also provides a comparative framework for understanding the ways in which that event took shape within a particular national setting. ${ }^{8}$ To develop that perspective, it examines the publication of 'Harlem: Mecca of the new negro' in the context of the aforementioned series of Race Issues in The Survey and then compares that publication to two of the more prominent issues in that series: the November 1921 issue, 'Irish anticipations', devoted to the Irish Renaissance and Irish nationalism, which included the work of leading Irish activists such as George Russell (henceforth referred to by his pseudonym, A. E.), W. B. Yeats, Horace Plunkett, and Erskine Childers; and the May 1924 issue, 'Mexico a promise', dedicated to the Mexican Renaissance in post-revolutionary Mexico, which included the work of such major Mexican figures as Diego Rivera, José Vasconcelos, and Manuel Gamio.

The argument that follows contends that American progressives found in these three renaissances a common concern with (re)defining the proper relationship between race and nation while they documented the unique circumstances which gave rise to very different conceptions of that relationship in each case. To post-war American progressives, the attraction to these and other such collective awakenings lay in the fact that they seemed to propose a robust national vision - a firm national ontology - that the United States seemed to lack: in the Irish case, the vision of a racially homogeneous nation-state premised on a repudiation of the colonizer and his culture; in the Mexican case, a syncretic nationstate based on the cultural and biological fusion of the colonizer and colonized; and in the Harlem case, a pluralist nation-state that held relatively autonomous races in something of a balance.

This essay contends, moreover, that recontextualizing the Harlem Renaissance in such a way has heuristic advantages. First, such a reorientation draws the Harlem Renaissance into a world-historical narrative in which it is but one instance of a wider set of challenges

6 This series of special issues of Survey Graphic included: 'Irish anticipations' (November 1921); 'The case for the Indian' (October 1922); 'Russian dreams, Russian realities' (March 1923); 'Mexico - a promise' (May 1924); 'Harlem: Mecca of the new negro' (March 1925); 'East-West' (May 1926); and 'An American look at fascism' (March 1927), The Survey and Survey Graphic, East Stroudsburg, PA: Survey Associates.

7 For a discussion of the complexities of race as a social construct, see Matthew F. Jacobson, Whiteness of a different color, Cambridge, MA: Harvard University Press, 1998; Wernor Sollors, Beyond ethnicity: consent and descent, New York: Oxford University Press, 1986; and Michael Omi and Howard Winant, Racial formation in the United States: from the 1960s to the 1980s, New York: Routledge, 1994.

8 The prevailing transnational narrative views the New Negro Movement as a chapter in the evolution of a diasporic black consciousness rooted in, among other things, the repercussions of the trans-Atlantic slave trade and race-based European imperialism. See Sonia Delgado-Tall and Nagueyalti Warren 'The New Negro Movement and the African heritage in a pan-Africanist perspective', Journal of Black Studies, 31, 3, 2001, pp. 288-310; and 'Pan-African cultural movements: from Baraka to Karenga', Journal of Negro History, 75, Winter-Spring, 1990, pp. 16-28, respectively. On the black diaspora, see Paul Gilroy, The Black Atlantic, Cambridge, MA: Harvard University Press, 1992; and Robin Kelly, "But a local phase of a world problem": Black history's global vision, 1883-1950', Journal of American History, 86, 3, 1999, pp. 1045-77. 
to Anglo-Saxon dominance in the post-war period. Second, it puts African-American intellectuals like Locke into a transnational conversation with intellectuals outside the United States who were sorting through similar questions of identity in the 1920s. And, third, it points us methodologically in the direction of world history by highlighting the political and cultural connections that tied such events together while casting those events in a comparative light so as to clarify the ways in which each was generic or unique.

\section{Racial and national renaissance in post-war progressivism}

The notion that the world was alive with renaissance can be felt throughout progressive writing in the post-war years. ${ }^{9}$ Important progressives like Jane Addams, Frank Tannenbaum, and John Collier were wholly convinced that theirs was a moment of rebirth characterized by a growing 'world consciousness'. ${ }^{10}$ The editor-in-chief of The Survey Paul Kellogg, for his part, certainly believed such renewal was in the air, proclaiming triumphantly in his opening remarks to 'Harlem: Mecca of the new negro' that times finally come when the 'forces that work so slowly and so delicately seem suddenly to flower' and 'the curtain [lifts] on a new act in the drama of part or all of us'. Such 'dramatic flowering', he said, characterized events in 'the New Ireland', in 'the newly awakened Mexico', and in the heart of America where 'a new race spirit [wa]s taking place among American Negroes'. ${ }^{11}$

This spirit of renaissance, be it in reference to Ireland, Mexico, Harlem, or elsewhere, was linked in progressive thought during these years to the notion of a revived racial spirit. Locke proclaimed, for instance, that African Americans were in the midst of a profound 'racial awakening' which had filled their lives with a 'renewed race spirit' palpable to anyone who cared to notice. The progressive social critic Frank Tannenbaum spoke similarly of a Mexican 'racial revival' that was likely to prove 'the greatest Renaissance in the contemporary world'. And Ireland's A. E. told American progressives that 'great currents of energy and thought in Ireland' foreshadowed the Gaelic race rising up to join the world's 'other races of genius'. ${ }^{12}$

Such proclamations of racial/national awakening were structurally bound to two major influences on progressive thought that date to these years - pragmatism and cultural pluralism. Pragmatism, for its part, redefined life as a fungible, open-ended affair by replacing the western legacy of philosophical idealism with the understanding that knowledge and truth were man-made constructs. Questioning the premise that life was governed by static, transcendent truths, it freed progressives intellectually to believe the world was plastic and

9 On progressivism, see Daniel Rodgers, 'In search of progressivism', Reviews in American History, 10, 4, 1998, pp. 731-36; Daniel Rodgers, Atlantic crossings: social politics in a progressive age, Cambridge, MA: Harvard University Press, 1998; and James T. Kloppenberg, Uncertain victory: social democracy and progressivism in European and American thought, 1870-1920, New York: Oxford University Press, 1986.

10 Dawley, Changing the world, p. 305.

11 Kellogg, 'Harlem: Mecca of the new negro', Survey Graphic, 1 March 1925, p. 627.

12 Locke, 'Harlem: Mecca of the new negro', pp. 629-34; Tannenbaum, 'Mexico - a promise', Survey Graphic, May 1924, pp. 129-32; A. E., 'Irish anticipations', Survey Graphic, November 1921, pp. 291-4. 
alive with endless renewal, rebirth, and renaissance. ${ }^{13}$ Likewise, the emergence of cultural pluralism in the progressive community in the years after the First World War structured the progressive perception of renaissance. As the horrors of the First World War came to light, progressives like Locke, Horace Kallen, Franz Boas, and Randolph Bourne increasingly tested the progressives' faith in the virtues of western civilization and unilinear progress and directed their attention outwards towards the world's other cultures for inspiration. ${ }^{14}$ That turn to pluralism, or in contemporary parlance, cosmopolitanism, was the ideological impetus of the aforementioned Race Issues of The Survey.

The most important consequence of these epistemological changes was a dramatic transformation in the progressives' understanding of the relationship between race and culture. While mainstream thought was dominated by a misguided faith in eugenics and social Darwinism, which supposed that more or less immutable breeds of inferior peoples were polluting an otherwise healthy human gene pool, post-war progressives came to argue that differences in aptitude and behaviour had their origins planted in culture rather than biology or nature. ${ }^{15}$ This ultimately pointed to the conclusion that races and nations were social constructions rather than a priori facts and that they might consequently be revamped in the seemingly most essential of ways.

Still, old presumptions did not die over night. The belief that human identity was tied to fairly stable strains of descent continued to exert an influence on progressivism in these years. There thus remained in this period a notable confusion among progressives between what the historian Werner Sollors has called the ideas of descent and consent, and that confusion could not help but register in the progressives' understanding of renaissance. ${ }^{16}$ As will become clearer, the discourse of renaissance, on the one hand, naturalized the notion of race and nation in that it presupposed already present but dormant identities were waiting to be reborn, while, on the other, it suggested in seemingly direct contradiction that new nations and races could actually be called into being.

Throughout The Survey, bold proclamations of a revived Gaelic, Negro, or Mexican spirit were regularly attended by a countervailing hesitancy at odds with such strident claims. A. E., for example, referred to the anticipation of a new Irishman rather than a new Irishman himself; Locke to the making of a Negro race rather than simply the New Negro himself; and Tannenbaum to the promise of a new Mexican race rather than its de facto existence. ${ }^{17}$ Pronouncements of renaissance in these years were thus prophetic gestures as much as they were statements of fact, and they hung, equally and uncomfortably, on notions of both consent and descent. The significance of

13 On pragmatism, see Louis Menand, The metaphysical club, New York: Farrar, Straus, and Giroux, 2001; John Patrick Diggins, The promise of pragmatism, Chicago: Chicago University Press, 1994; and Kloppenberg, Uncertain victory.

14 On cultural pluralism, see Everett H. Akam, Transnational America: cultural pluralist thought in the twentieth century, Lanham, MD: Rowman and Littlefield, 2002, p. 8.

15 On Boas, see George Stocking, Race, culture, and evolution, Chicago: University of Chicago Press, 1982. On Park's conception of racial difference, see 'Our racial frontier on the Pacific', Survey Graphic, 1 May 1926, pp. 192-6.

16 Sollors, Beyond ethnicity.

17 Locke, 'Harlem', Survey Graphic, pp. 629-34; Tannenbaum, 'Mexico - a promise', Survey Graphic, pp. 129-32; A. E., 'Irish anticipations', Survey Graphic, pp. 291-4. 
the particular identities to which renaissance gave life in Ireland, Mexico, and Harlem in this period becomes clearer as we turn, as American progressives of the time did, to each.

\section{Irish Renaissance: the Gaelic revival and the Irish Free State}

The November 1921 issue of The Survey dedicated to the new Ireland was the prototype for the successive renaissance issues published annually over the course of the next decade by The Survey staff. It set the pattern for future issues like Harlem: Mecca of the new negro by documenting the type of aesthetic and political groundwork being done across the globe to remake races and nations. Although in some respects 'Irish anticipations' was a less impressive publication than those to come, it contained the work of important Irish intellectuals, artists, and activists, including, among others, the philosopher and writer, A. E.; the leading figure in rural reconstruction, Horace Plunkett; the dominant figure of the Irish Renaissance, W. B. Yeats; and the soon-to-be executed leader of the Irish resistance, Erskine Childers.

'Irish anticipations' put American progressives in direct dialogue with Irish revivalists. As an historical document, it was not simply a summation of Irish culture and politics but a political statement on Irish nationalism, and one that was especially suited to progressive political sensibilities. 'Irish anticipations' was in many respects, as we will see, a benign simplification of Irish nationalism which omitted such unseemly aspects as its ethnocentrism and violence as well as the political complexities of Irish-English relations. ${ }^{18}$ 'Irish anticipations' thus provides us with a rich historical perspective on Irish nationalism as well as a glimpse of how the politics of renaissance played itself out, at least in one case, on the global stage.

By November 1921, when 'Irish anticipations' was published in the United States, the Irish Renaissance had seen its heyday. What was historically momentous in these years was not the Irish Renaissance itself so much as the political consequences of that renaissance. In this period, the cultural nationalism of the renaissance had ceded the limelight to the political nationalism that produced an Irish Free State. In the years preceding the publication of 'Irish anticipations', Irish nationalists, building on the momentum of a Young Ireland movement and the Gaelic Renaissance, staged the famous Easter Uprising of 1916 and conducted through 1921 a war of resistance against the Royal Irish Constabulary and the English occupation. Having solicited international support from Russia, Germany, and the United States during the First World War (a war which at least the Allies claimed had been fought for national self-determination), Irish nationalists had declared independence from England, repudiated ties to the Union (of Great Britain and Ireland), abandoned the British parliament in Westminster, and founded an alternative Irish parliament in Dublin. In the years leading up to 1921, this parliament, the Dáil Eireann, along with a volunteer army of nationalists had come to manage Irish affairs and represent Ireland to the world.

18 For a more thorough portrait of the complexities of the Irish Renaissance, see Seamus Deane, Strange country: modernity and nationhood in Irish writing since 1790, New York: Oxford University Press, 1997, p. 53, and Declan Kiberd, Inventing Ireland, Cambridge, MA: Harvard University Press, 1996. 
By 1921, England had capitulated to the court of world opinion and the impact of continued Irish resistance and granted to Ireland legislative, executive, and judicial sovereignty over all but the Ulster provinces in the north. ${ }^{19}$ 'Irish anticipations' came out just as this Irish Free State was emerging on the world scene.

The Survey chose a good starting point in Ireland. To the American progressive who believed in the possibility of reconstructing modernity and its subjects along new collective lines, Ireland in 1921 seemed proof that he or she was not chasing after phantoms. Events in Ireland seemed to testify to the fact that the slow work of cultural production mattered, that the work of artists, historians, and writers could over time recast the discursive infrastructure of racial and national identity and pave the way for new forms of political solidarity and action. Developments in Ireland confirmed what American progressives like those writing for The Survey had been saying all along: politics and aesthetics were two sides of the same coin. ${ }^{20}$ Contemporary Irish history seemed to offer, in other words, conclusive proof that revitalizing the political sphere and remaking citizens necessitated reconstructing consciousness through something like a national renaissance. Moreover, and as importantly, American progressives were drawn to Irish independence because it struck a strong note for racial and national distinctiveness that resonated with their growing affinity for a pluralist politics based on difference.

Ireland claimed its rights to nation-state status on a particularist vision of a resurrected Gaelic self. Drawing on the work of renaissance writers and artists, Irish nationalists of this period envisioned a post-colonial state built upon the rebirth of a Gaelic nation/race that had been suppressed during centuries of English rule. Although there were always disagreements as to what constituted Irish identity, Irish nationalism in this period centred in the main on three claims. The first was that Ireland was a culturally distinct nation; the second that Irish culture had 'been mutilated beyond recognition by British colonialism'; and the third that Ireland's lost past could be recovered and given a political form suitable to life in the modern world. ${ }^{21}$ The nationalists' claim to independence thus drew its legitimacy from the idea that a distinctive Gaelic culture, buried beneath centuries of English rule, still resided in the bodies of a Celtic race that was waiting to be reborn in the twentieth century. Such claims ultimately supported a post-colonial subaltern identity that contrasted with the accommodationist, assimilationist, and civic ideas of an Irish people put forward by proUnionists and advocates of Home Rule.

The meta-narrative that took hold in Ireland during these years articulated a racial vision of the nation-state that gave symbolic form to an idealized national body based on an uncomplicated line of ethnic descent. While Irish nationalism was also a cultural affair, it was always bound to this racialized narrative that presumed an unproblematized Gaelic body which had passed through time despite all efforts at eradication and assimilation. Nationalists imagined that it was from within this yet intact Gaelic body that a distinctive and independent Irish nation might reemerge. As we will see, such a presumption gave

19 James Lydon, The making of Ireland: from ancient times to the present, New York: Routledge, 1998.

20 On the connections between art and politics in progressive thought, see Casey Blake, Beloved community: the cultural criticism of Randolph Bourne, Van Wyck Brooks, Waldo Frank, \& Louis Mumford, Chapel Hill, NC: University of North Carolina Press, 1990. 
rhetorical power to Irish claims to independence while it simultaneously encouraged a national ideal that was more exclusionary at root than the ideals promoted in the Harlem or Mexican renaissances.

Whether or not the Irish Renaissance was primarily a racial affair is less significant than we might first suppose, ${ }^{22}$ for the references to a Gaelic race whenever they did turn up struck an emotional register far deeper than the less mystifying debates over the complex relations between Anglos and Celts, Protestants and Catholics, landlords and tenants that comprised Ireland's history. A. E., for instance, evoked a sort of racial sublime at the end of his otherwise tempered lead article for The Survey. Having explained to the American progressive in pedestrian prose that the political claims to an independent Irish homeland flowed from four concrete developments - from the struggle for political liberty after the manner of the French and American Revolutions led by men like Michael Collins; from the emergence of the agricultural cooperative movement headed by Horace Plunkett; from the claims of labour unions for control over production; and from the unprecedented revival of Gaelic thought and culture led by figures such as Yeats and Lady Gregory - A.E. discarded quotidian politics for a mystical declaration of the destiny awaiting modern Gaels, a race which, he claimed, had begun among the gods in a time barely remembered:

I cannot believe that the legend of the Gael, which began among the gods, will die out in some petty peasant republic or dominion as a river which rose among the mountains might eddy at last in mud flats and the sewage of squalid cities. What began greatly I think will end greatly, and there will be some flare-up of genius before the torch of the Gael is extinguished and it becomes like the torch once held by the Greeks and other races of genius which are now but memories in the Eternal Mind. ${ }^{23}$

Such race pride was reinforced in 'Irish anticipations' with poems by Yeats and Padraic Colum. In 'The fair hills of Eiré O', Colum, for instance, told of Ireland's descent from 'Eivir's race' in the hills of Ireland where a psychically (if not physically) displaced people yet survived, longing for their return to homeland and kin. And Yeats's 'To Ireland in the coming times' summoned for the American progressive a timeless Gaelic past that flowed beneath the mutilated Irish present. Yeats captured the spirit of renaissance in this famous poem by proclaiming a mythic origin during which Ireland's 'heart beg[a]n to beat' and promising his fellow Irishmen that their moment had not yet passed, for 'elemental beings' like 'Davis, Mangan, and Ferguson' still moved about the air of the present like 'flood and fire and clay and wind'. In such works as these, Ireland was not a mere political innovation, it was the incarnation of a race and nation that had been in waiting since the 'world's first blossoming age'. ${ }^{24}$ Renaissance writing such as this ultimately worked to endow the events of the 1910s and 1920s with the substance of a racial awakening by giving emotional depth to developments that might otherwise have been cast as merely political.

22 One might argue that religion rather than race was the important fault-line in divisions between Irish nationalists and their opponents. The relevant question in this case is not whether or not religion or race is the important line of division but to what extent religious difference is constituent of racial difference.

23 A. E., 'Irish anticipations', Survey Graphic, p. 294.

24 Padraic Colum, 'The fair hills of Eire O', and W. B. Yeats, 'To Ireland in the coming times', Survey Graphic, November 1921, pp. 294, 304. 
The idea of renaissance in the Irish imagination as well as in the American progressives' implied the creative act of remaking a nation and its people, but it also contained in the Irish case (understandably, given the excesses of British colonization) a less tolerant strain of racial descent. Such untoward aspects of Irish nation-building made it marginally into the pages of 'Irish anticipations' in a contribution by an Ulster unionist named Richard Rowley. Rowley seized on the phantoms of racial purity as one of the primary lines of division separating the northeastern Ulster provinces from those that were to become the Irish Free State. As Rowley saw the state of affairs in 1921, racial antagonisms divided the northeastern provinces from the rest of Ireland. The dominant 'Celtic Irish', he claimed, bore a racial identity that distinguished them from the Ulster population which retained 'unmistakably the characteristics of the Saxon race'. And that racial cleavage, he said, had become over time so thoroughly tied up in economic and religious conflicts that it was no longer possible to distinguish in the Irish case among religious, class, and race conflict. ${ }^{25}$ In framing things in such a way, Rowley reminds us that the narrative of racial descent that legitimated Ireland's claims to nation-state status was in the minds of unionists and nationalists alike inextricable from other narratives of political, economic, and cultural conflict. In such a context, race naturalized and simplified conflict that was notably more complex and ambiguous than either Irish nationalists or unionists like Rowley claimed it to be.

The dominant nationalist discourse of this period in Ireland, therefore, did not fit as neatly within the progressive narrative of a multicultural world as did the pluralist and syncretic developments in Harlem and Mexico. Irish nationalists did, however, address themselves in 'Irish anticipations' to a more cosmopolitan international community of progressives outside of Ireland by offering two different versions of Ireland's role in the imagined global community. The Irish writer James Stephens explained that the rebirth of Ireland would be followed by a period of defensive solitude wherein nationalists would set about 're-gaelicizing the nation' and 'imposing the barrier of language' between themselves and the English. During such a time, Stephens claimed, Irishmen would abandon the 'foreign tongue' for a Gaelic one more suitable to the 'Irish mind' and pave the way for the 'resurgence of Gaelic culture'. As 'Ireland returned to her fountains', he said, it would 'retire from England...from the world, and, like some happy anchorite[,]... live in contentment, unheard of, unminded, until the time comes for her to do whatever work the gods assign her'. Stephens proposed a future in which Ireland might simply remove itself from world affairs and perhaps even from modern times 'never again [to] have a history'. ${ }^{26}$

The more cosmopolitan A. E. supposed a different future for Ireland. Although markedly unsure of the direction the future was to take, A. E. imagined that the new Ireland would not retire from but rather take an active part in world history. While he agreed with Stephens that an independent Ireland would need to replace the 'characterless culture' of colonialism with a reclaimed Gaelic heritage, in contrast to Stephens, he imagined Ireland as playing an active part in a cosmopolitan world. Quoting international authors as diverse as Walt Whitman and Laotze, A. E. imagined that rather than retire from the world and abandon the English language, great numbers of Irishmen would 'ransack world literature

25 Rowley, 'Ulster's position', Survey Graphic, November 1921, pp. 299-301.

26 Stephens, 'Ireland returns to her fountains', Survey Graphic, November 1921, pp. 302-4. 
and science for truth' and seek ways to 'graft onto it[self] those fundamental and universal ideas without which the intellectual life of a nation would be barren and ... provincial'. ${ }^{27}$ A. E. did not go so far as to envision Ireland itself along pluralist lines, but he did imagine the island as part of a world where small, post-colonial nations like it would contribute to a larger pluralist world culture. Such a world was precisely the world that American progressives were coming to want.

Before moving on, let us note that the patterns in the Irish case reflect those which we will see shortly in the Mexican and Harlem cases. The conscription, for instance, of an exclusive racial past into the making of the new Ireland was a manifestation of a more general structure of renaissance in the world at large. The Gaelic revival and the type of nationalism it engendered were, in fact, products of a broader, global modernizing process that called into being such narratives of rebirth and recovery. ${ }^{28}$ Renaissance like that of the Irish, that is to say, ultimately made possible the collective fictions of race and nation on which modern politics turned, providing nation-states like the new Ireland with the discursive legitimacy, meaning, and substance they relied on both domestically and globally. What is important to reiterate before proceeding is that renaissances such as this did not ultimately revive pre-modern identities so much as they naturalized what were in fact human contributions to the making and remaking of races and nations. In this respect, the Irish route into the modern world was, as we will see, structurally similar to that of African Americans in Harlem and Mexicans in post-revolutionary Mexico.

\section{Mexican Renaissance: la raza cosmica and state-sponsored cultural revival}

The journalist and historian Frank Tannenbaum began the 25 April 1924 issue of The Survey by asking American progressives 'to stand humbly before a people come to life'. Others writing for this special issue, 'Mexico - a promise', claimed that Mexico was in the midst of 'one of the most amazing political, cultural, and economic developments of the decade'. ${ }^{29}$ This post-war revival, they said, had as its only parallel the 'great prototype' of renaissances - the Italian Renaissance. 'Just as Boccaccio, Leonardo, [and] Galileo voiced the spirit of the Italian Renaissance', American progressives claimed, 'so do Rivera, Gamio, Vasconcelos, Atl and others... make articulate the promise of a new day in Mexico'. ${ }^{30}$

Such progressives identified several developments in post-war Mexico that suggested it was in the midst of an unprecedented historic revival. The emergence of a revolutionary racial ideology that claimed the Mexican mestizo as the epitome of evolutionary development, the resuscitation of cooperative control of agriculture in the form of the ejido, and a cultural renaissance in the arts headed by the famous Mexican muralists - together,

27 A. E., 'Irish anticipations', Survey Graphic, p. 294.

28 Deane, Strange country, p. 51.

29 Tannenbaum, 'Editorials', Survey Graphic, 1 May 1924, p. 186.

30 Social Welfare History Archives, University of Minnesota, Minnesota, Survey Associates Records, 195, 1552, 'Press Release: Mexico - a promise'. On the Mexican Renaissance, see Mackinley Helm, Mexican painters: Rivera, Orozco, Siqueiros and other artists of the Social Realist School, New York: Dover 1989. 
these seemed to progressives clear indications that the world was witnessing the rebirth of a nation and its people. The history of Mexico in these years looks different to us than it did to progressives of the time, since we know today that Mexico would ultimately fail to live up to the hyperbolic rhetoric that surrounded its post-war reconstruction, but to progressives writing in the 1920s, Mexico was in the midst of a renaissance of world-historical import.

Like 'Irish anticipations', the special 1924 issue of The Survey dedicated to the Mexican Renaissance, 'Mexico - a promise', provides one of the more interesting perspectives we have on the cultural politics of the post-war era. Carrying articles from prominent Mexican intellectuals and statesman and from influential American social reformers, it, like 'Irish anticipations', provides us both with evidence of a direct transnational dialogue between progressives in the United States and their counterparts abroad and with a rich contemporary interpretation of the remaking of a nation in the post-war period. ${ }^{31}$

As an historical document, 'Mexico - a promise' reproduced almost without exception the 'official transcript' of Mexican nationalism. ${ }^{32}$ The voices of the Mexican elite dominated its pages: Plutarco Elías Calles, soon-to-be Mexican president; José Vasconcelos, Minister of Education and the public figure most responsible for the cultural revival in Mexico; Manuel Gamio, Mexico's pre-eminent anthropologist; Ramon de Negri, Mexico's Secretary of Agriculture and the person in charge of the nation's rural reconstruction; Dr Atl, an influential Mexican ethnographer and founding figure in Mexico's cultural revival; and Diego Rivera, the nation's pre-eminent state-sponsored artist. Moreover, the introductory piece to the edition was written by Frank Tannenbaum, the leading American pioneer of Latin American Studies who had personal connections with the post-war Mexican elite. ${ }^{33}$

'Mexico - a promise' was a timely look at Mexico. By the mid-1920s, Mexico had entered a period of reconstruction after the more than ten years of civil war which followed the overthrow of the neo-liberal dictatorship of Porfirio Diaz in 1910. In these years, the revolutionary elite consolidated power and launched out on a crusade to make the nation over culturally, economically, and politically. ${ }^{34}$ The economic and political project of the post-revolutionary elite entailed an ambitious programme in agrarian and social reform which included both the reintroduction of collective ownership of land and the adoption of a radical constitution that seemed to guarantee a number of sweeping improvements in labour relations and social welfare. As in the Irish case, Mexican elites believed that

31 Jesus Velasco, 'Reading Mexico, understanding the United States', Journal of American History, $86,2,1999$, pp. 642-5.

32 James C. Scott uses the term 'official transcript' to denote the public, often state-sponsored, discourses that circulate in society. He contrasts that discourse with what he terms a 'hidden transcript' that exists at the grassroots and contests the hegemonic interpretations of the official transcript. The only contribution to 'Mexico - a promise' that served to qualify the dominant voices in this publication was that of Felipe Carillo Puerta, the recently deceased Mayan rebel who stressed an indigenous, regional vision for Mexico's future. See Felipe Carrilla Puerta, 'The new Yucatan', Survey Graphic, May 1924, pp. 138-42.

33 Calles, 'A hundred years of revolution', pp. 133-4; Vasconcelos, 'Educational aspirations', pp. 167-9; Gamio, 'The new conquest', pp. 143-6, 192-4; de Negri, 'The agrarian problem', pp. 149-52; Dr Atl, 'Popular arts of Mexico', pp. 161-4; Rivera, 'The guild spirit in Mexican Art', pp. 174-8; and Tannenbaum, 'Mexico - a promise', pp. 129-32 in Survey Graphic, May 1924. On Tannenbaum, see Charles Hale, 'Frank Tannenbaum and the Mexican revolution', Hispanic American Historical Quarterly, 75, 2, 1995, pp. $215-46$.

34 Leonard Folgarait, Mural painting and social revolution in Mexico: art of the New Order, New York: Cambridge University Press, 1998. 
successful economic and political reconstruction depended upon the reconstruction of the nation's history, culture, and identity. Post-war reconstruction seemed, that is, to hinge on rescripting the racial and national imaginary of Mexico in such a way as to draw its various peoples, classes, and factions into a shared story of progress. In marked contrast to the Irish case, which emerged from subaltern activity, substantial federal monies were allocated in this period to the cultural apparatus of the Mexican state in the hopes of summoning such a national identity into being. The Mexican Renaissance that came of this was consequently a cultural revival sponsored by the state and reflective of the larger nation-building objectives of Mexico's post-revolutionary elite.

At the symbolic centre of the Mexican Renaissance was a redefinition of the relationship between race and nation. Three figures whose work appeared in 'Mexico - a promise', Vasconcelos, Gamio, and Rivera, all played especially important roles in articulating the new narrative of race and nation that came out of Mexico in these years. The central figure was, Vasconcelos, who as the Minister of Education commissioned and oversaw the Mexican mural movement, the state's educational projects, and various other propaganda activities, and thus exerted an unparalleled influence on the Mexican Renaissance. An intellectual of global stature, Vasconcelos also articulated the most important revision of race theory to come out of Latin America during the early twentieth century. In a highly publicized challenge to the racist assumptions of social Darwinists on both sides of the Atlantic, Vasconcelos proposed in the 1920s a theory of racial evolution, la raza cosmica, that placed Mexico's mestizo race at the forefront of human evolution. Directly counter to the hegemonic claims of the world powers of the day, Vasconcelos declared that it was not the genetically pure and attenuated Anglo-Saxon race that would lead the world into the future but rather the more racially fluid ones (created from the best traits of multiple races) like the Mexican mestizo that would do so. The ideological tenets of la raza cosmica saturated the state's cultural project in these years and came to function as the official creed of the new Mexico. ${ }^{35}$

Manuel Gamio, head of the nation's Department of Anthropological Research and, after Vasconcelos, the country's most important figure on matters of racial thought, introduced American progressives to Mexico's new racial creed in 'Mexico - a promise'. In an article entitled 'The new conquest', Gamio explained that his nation had rejected the principles of racial hierarchy that prevailed in the western world in favour of a revolutionary new 'national synthesis' that celebrated the nation's racial hybridity. That new synthesis was to emerge from the 'reciprocal contributions' of 'Mexico's various racial groups' and would eventuate in nothing less, Gamio said, than a total 'realignment of the [nation's] races'. As Gamio saw it, the Mexican state's newfound commitment to 'racial understanding', to 'a fusion of different cultures', and to 'linguistic unification' would give to the country its first 'coherent national consciousness' by joining the nation's races in a single mestizo ideal. ${ }^{36}$

Diego Rivera's murals were to give visual expression to that ideal. In The Survey, a reproduction of the 'Sugar Refinery' (a section from the mural on the walls of the Ministry of Education building) offered a portrait of Mexico that incorporated the nation's

35 Alan Knight, 'Racism, revolution, and indigenismo: Mexico, 1910-1940', in Richard Graham, ed., The idea of race in Latin America, 1870-1940, Austin, TX: University of Texas Press, 1990, pp. 71-117.

36 Gamio, 'The new conquest', Survey Graphic, May 1924, pp. 143-6. 
Figure 2. Diego Rivera, 'Sugar refinery', Survey Graphic, May 1924. Mislabelled here as 'Metal workers'

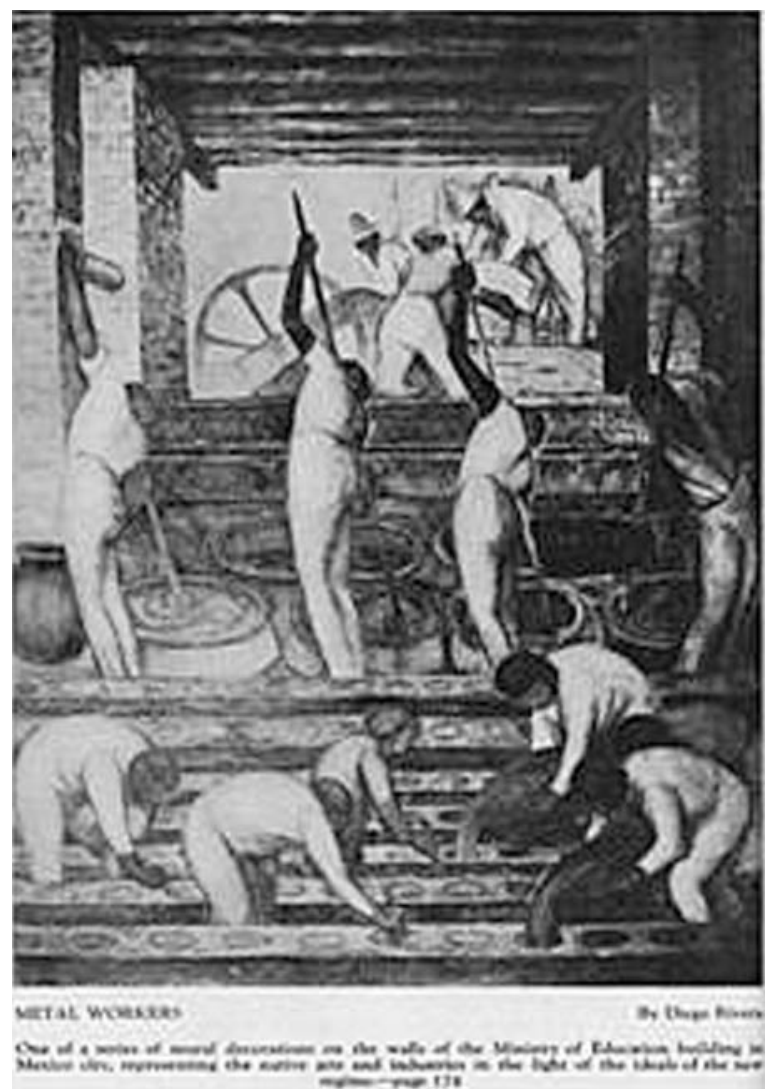

indigenous peoples into the new narratives of racial and national progress advocated by the Mexican state (Figure 2). ${ }^{37}$

The mural, reproduced here, centres on a group of three Indian men, stirring liquid sugar in rhythm, their bodies arched in unison, left arms raised to the tip of a body-length puddling stick, right arms and hands tensed low on the stick to gain leverage in the stirring, the workers arranged in such a way as to downplay their individuality and reinforce the collective nature of their enterprise. In the foreground, five other indigenous labourers are methodically at work casting the sugar into a series of bowls, two pouring the liquid, three moulding the sugar in a long series of casts. The mural gives the impression of an organic machine made up of indigenous bodies busily and comfortably working to build a new Mexico, with the collective and non-mechanized nature of the work suggesting a pace and quality of modernization peculiarly Mexican.

'Sugar Refinery' functioned iconographically to represent the new narrative of race and nation in Mexico by combining a Mexican past - with its human rhythms, its cooperative

37 'Sugar Refinery' was mislabelled in The Survey as 'Metal Workers'. Rivera, 'Metal workers', Survey Graphic, May 1924, p. 128. 
life, and its indigenous and syncretic history - with the promise of a modern future, its assembly lines, its commercial character, and its industrial order. Rivera himself explained that his murals stood at the intersection of race and nation. He told the American writer Katherine Anne Porter in an interview that they captured the spirit of 'a whole nation' which was just beginning to 'evince the astounding fullness of [its] genius'. In a way strikingly similar to his Irish counterpart, A. E., Rivera explained that 'every such race ... experiences [an] epoch of lofty intellectual and spiritual development ... a culmination of centuries of preparation, centuries wherein the race grows gradually in the love and understanding of art and...the power of projection'. ${ }^{38}$

Rivera's murals repudiated the explicit racism of the creole-centred ideology that had dominated Mexican history and thus fundamentally changed the ways in which the relationship between race and nation would be discussed in Mexico thereafter. But the new narrative that came out of this moment was, like its forebears and its Irish counterpart, a fairly sanguine vision of a people that downplayed racial and national conflict. The theory of a single cosmic race in Mexico, for instance, depended on a substantial elision of political and cultural differences within the country. Most notably, it depended on de-legitimizing such alternative political visions for Mexico as the grassroots racial pluralism espoused by the nation's indigenous peoples. ${ }^{39}$ The Mexican Renaissance that we learn about in The Survey was, that is to say, as much a conquest in the name of renaissance as it was an indigenous racial revival.

The nature of that conquest was most visible in the title and details of Gamio's contribution to The Survey. To a nationalist architect like Gamio, the development of 'a coherent national consciousness' required 'a new conquest' of Mexico. Building 'a true patria', as Rivera had put it in his conversation with Porter, required a staggering, state-sponsored modernizing programme in linguistic unification, industry, and education. In practice, that meant sending creole and mestizo missionaries into Indian villages with an assimilationist agenda that included not merely tutorials in reading and writing but a laundry list of western lessons in 'industry, commerce, agriculture, hygiene, morality, [and] civics'. ${ }^{40}$ Renaissance, as nationalists like Gamio would have it, was thus to be worked out on the bodies and minds of the Mexican Indian as he or she was urged for the sake of national unity into western capitalist markets, western modes of farming and industry, a western model of citizenship, and western notions of dress, behaviour, and morality.

Despite such complicating details, the Mexican Renaissance, like the Irish case, fits within a progressive discourse of cultural pluralism. The promise of a people evolving into a cosmic race out of their independent racial pasts reaffirmed the progressive belief that races were plastic and evolving, that they might yet live in harmony, and that each race, new or old, had a unique contribution to make to an increasingly connected cosmopolitan world. Adapting Mexican nationalism to the post-war narrative of global renaissance, however, meant in the Mexican case digesting the official self-portrait offered by Mexican elites without ever adopting the type of critical stance that would have more clearly identified

38 Rivera, interviewed by Katherine Porter, 'The guild spirit in Mexican art', Survey Graphic, May 1924, pp. 174-8.

39 Knight, 'Racism, revolution', pp. 71-117.

40 Gamio, 'The new conquest', pp. 144-6, 192-4. 
the possibilities and liabilities of building a progressive nation-state after the manner pursued by Mexican nationalists in the 1920s.

We now return full circle to Harlem, where progressives encountered yet a third configuration of post-war renaissance. In Harlem, progressives met a domestic subaltern renaissance aimed not so much at nation-building, as were the previous examples, but at the rebuilding of a white supremacist nation-state that had circumscribed the literal and symbolic terrain in which its most significant minority group moved.

\section{Harlem Renaissance: the politics of the New Negro narrative}

'Harlem: Mecca of the new negro' introduced American progressives to the leading figures of the Harlem Renaissance. Edited by Alain Locke and with contributions from both African Americans and black emigrants to the United States, it announced to the world a racial awakening of global import. Harlem writers and artists proclaimed in this issue of The Survey that a black self, pan-African in scope and substance, had reawakened in Harlem and set out, as Locke explained, to rehabilitate the race 'in world esteem'. ${ }^{41}$ The Harlem Renaissance was thus according to progressives like Locke a vital national event with world-historical implications, an episode in a meta-narrative of post-war renaissance as well as a key development in the emergence of a new diasporic black identity.

As with the previous two cases, the Harlem Renaissance was a politicized affair aimed at rewriting the racial and national imaginary of the nation-state. The United States, as the site of that renaissance, however, shaped its cultural politics in ways markedly different than in the Irish and Mexican cases. The demographic realities of race in the United States, where African Americans comprised less than $10 \%$ of the national population, did not point towards the formation of a post-colonial nation-state as in Ireland, where Celts comprised a vast majority of the national population. ${ }^{42}$ And a strictly imposed colour line in the United States, which in the early twentieth century included state-supported racial segregation, preempted the development of a discourse of racial amalgamation like that which developed in Mexico's predominately mestizo society. Consequently, the politics of renaissance in Harlem took on a shape uniquely American.

The basic features of the Harlem Renaissance are fairly straightforward. Its social origins lay in the new black communities of the northern United States that had emerged with the large-scale internal migration of African Americans (along with a transnational migration of peoples from elsewhere within the African diaspora) to northern manufacturing centres after the First World War, and the subsequent ghetto-izing of such migrants in neighbourhoods like Harlem. In terms of periodization, the Harlem Renaissance began with the return of African American troops during post-war demobilization and ended in the 1930s with the onset of an economic depression that struck African Americans harder than anyone else. In terms of substance, it was an elite-driven, urban cultural revival spawned by black

41 Locke, 'Enter the new negro', pp. 632-3.

42 Frank Hobbs and Nicole Stoops, US Census Bureau, Census 2000 Special Reports, Series CENSR-4, Demographic trends in the 20th century, Washington DC: US Government Printing Office, 2002, p. 75. 
artists, poets, novelists, philosophers, musicians, and activists who believed that the power of art and the written word might be used to undermine the prevailing racial order in the United States and the trans-Atlantic world. ${ }^{43}$

Perhaps the most enduring legacy of the Harlem Renaissance was its challenge to the racial nationalism that had long prevailed in American society. American identity, as is well known, had been historically constituted in terms of racial exclusion. ${ }^{44}$ In the 1920 s, such exclusion included state-supported Jim Crow laws in the American South as well as a host of legal mechanisms across the country that worked to relegate African Americans to a second-class status. Black writers and artists who promoted the Harlem Renaissance in the United States thus found themselves in a situation different from both their Mexican peers who were supported by the state and their Irish counterparts who were a majority people. As the American context was amenable neither to the ideal of a racially syncretic nation-state nor to a black nation on North American soil, black activists in Harlem articulated a narrative of race and nation built on racial pluralism that was more in keeping with American conditions. The New Negro narrative they espoused was a carefully crafted discourse that accepted the prevailing post-war American consensus that racial differences existed, and mattered, but revised the meaning of such differences by locating them within a cosmopolitan nationalism.

Central to this project of renaissance was a revision of 'Negro' identity and the AfricanAmericans' role in the imagined national community. Locke's expositions of the New Negro narrative in The Survey were among the core statements of the movement. Locke claimed that an awakened black self, a 'New Negro', stood at the centre of developments in Harlem. That black self, he said, repudiated Uncle Tom-ism and the accommodationist tradition of conservative black elites; rejected the paternalistic race work of white liberals who urged an assimilationist model of race relations; and, in stark contrast to earlier efforts to downplay racial difference, claimed for themselves a racially distinct culture rooted in historic and biological ties to Africa. In short, not only did the New Negro view himself as the psychological and intellectual equal of white Americans, he was also newly awakened to the racial origins of the collective memory he carried within himself.

The New Negro narrative was structured by a rejection of the dominant discourses of race and nation that circulated in the early twentieth-century United States. Whereas the dominant narrative in the white community claimed blackness as a liability, and the dominant narrative among the black elite downplayed the relevance of race in order to facilitate assimilation, Locke and the new generation for which he claimed to speak declared a pride in their African heritage and their racial difference. ${ }^{45}$ Locke expressed this feeling of race pride quite explicitly in his writings, claiming that the sudden birth of

43 There is disagreement in the historical profession over the significance of the Harlem Renaissance. Scholars like Lewis have criticized it as merely 'an arts and letters movement'; while others like Huggins have viewed it as a pivotal moment in the growth of modern African-American identity. See Harlem renaissance and When Harlem was in vogue, respectively.

44 Gary Gerstle, American crucible: race and nation in the twentieth century, Princeton, NJ: Princeton University Press, 2002; Reginald Horsman, Race and manifest destiny, Cambridge, MA: Harvard University Press, 1986; Winthrop Jordan, White over black, Chapel Hill, NC: University of North Carolina Press, 1968; and David Roediger, The wages of whiteness, New York: Verso, 1999.

45 For a portrait of American racial thought in this period, see Lee Baker, From savage to negro, Berkeley, CA: University of California Press, 1998. 
a New Negro had in fact issued from a 'deep feeling of race' that was 'the mainspring of Negro life' and which currently guided him in his efforts to rehabilitate his race 'in world esteem'. ${ }^{46}$

Such rehabilitation meant, among other things, reclaiming blackness from the base position it held in western culture. Renaissance writers famously stressed the beauty of the black body in order to wrestle the meaning of blackness away from the hands of social Darwinists, eugenicists, and others of their ilk. In striking verse, Langston Hughes likened the coming of dusk to his own body, 'Rest at pale evening, / A tall, slim tree, / Night coming tenderly / Black like me'. And poets like Angelina Grimke wrote that she had 'just seen a most beautiful thing / Slim and still, / Against a gold, gold sky, / A straight black cypress, / Sensitive, / Exquisite, / A black finger / Pointing upwards'. ${ }^{47}$ Such pronouncements in The Survey were a small part of the much broader project of resignifying the meaning of blackness and of black peoples in western culture.

To Harlem writers, rehabilitating the race also meant resuscitating African-Americans' claims to an African past. The New Negro, they argued, was a transnational phenomenon with deep roots in an African past that wed peoples of African descent from the United States, the Caribbean, and elsewhere into a common experience and history. Such panAfrican sentiments were legion in the Harlem Renaissance. As just one example, Countee Cullen's poem Heritage famously meditated on the African-American's relationship to Africa, beginning with the lines, 'What is Africa to me?', and running through a series of potential answers to that question in the stanzas to follow. ${ }^{48}$ But in an even more corporeal sense, the presence in The Survey of the writings of West Indian emigrants to Harlem, like W. A. Domingo and Claude McKay, testified to the pan-African scope of developments in Harlem.

This emphasis that writers and artists placed on race was, however, not the predicate to a separatist agenda (as it was, for instance, in Marcus Garvey's pan-African movement of the same period). In contrast to the exclusionary tendencies in a case like that of the Irish, the New Negro narrative explicitly disavowed the notion of racial separatism in political matters. The New Negro narrative emphasized in no uncertain terms that African Americans were reclaiming rather than rejecting a nation that was as much their own as any Anglo American's. As Locke put it, the New Negro reached out 'to nothing but American wants [and] American ideas', auguring 'a new democracy in American culture' rather than its Balkanization. ${ }^{49}$ Similarly, James Weldon Johnson asserted that 'Harlem talks American, reads American, [and] thinks American'; while poets like Hughes put such nationalist sentiments to verse: 'I, too, sing America / I am the darker brother. / They send me to eat in the kitchen' though 'Tomorrow ... / ... they'll see how beautiful I am / And be ashamed, - / I, too, sing America'. ${ }^{0}$

\footnotetext{
46 Locke, 'Enter the new negro', Survey Graphic, March 1925, pp. 632-3.

47 Hughes, 'Dream variation' and Grimke, 'The black finger', Survey Graphic, March 1925, pp. 661, 664.

48 Cullen, 'Heritage', Survey Graphic, March 1925, pp. 674-5.

49 Locke, 'Enter the new negro', pp. 632-3.

50 James W. Johnson, 'The making of Harlem'; Langston Hughes, 'I, too', Survey Graphic, March 1925, pp. 639, 676 .
} 
That emphasis on inclusion ultimately meant that the Harlem Renaissance took shape within a reformist framework that appealed to mainstream liberal-democratic ideals. And yet the rhetorical and political impact of Harlem Renaissance writings and art came to focus less on this message of solidarity than on the more provocative claim made by influential African Americans that racial differences indeed mattered. This shift among black activists towards a theory of racial pluralism held out the promise of black liberation (if only in the symbolic realm) from a culture that denigrated peoples of African descent, but it also, as many knew at the time, risked reaffirming the racialist premises that had supported such race-based policies as segregation. As writers like Locke understood it, the success of the Harlem Renaissance project and its New Negro narrative thus ultimately depended on a reclamation of racial difference that did not threaten to dwarf the principle of a shared national identity.

Representing difference was consequently a delicate political matter. Although the Harlem Renaissance produced no final consensus on this score, many writers and artists of the period did venture, if cautiously, to sketch the contours of black difference. Locke, for instance, claimed that blacks had a natural 'humor, sentiment, imagination and tropic nonchalance' that distinguished them in character from their white counterparts and suggested that such traits might help to balance out an otherwise materialistic and over-worked Anglo nation. ${ }^{51}$ Similarly, the West Indian émigrés W. A. Domingo and Claude McKay depicted blacks as naturally imaginative and nonchalant, suggesting they carried within themselves 'palm fringed sea shores, murmuring streams, luxuriant hills and vales / ... [b]ananas ripe and green, / ... memories / Of fruit-trees laden by low-singing rills' ${ }^{52}$ The general tenor of these writings was that a more natural and rhythmic self, descended from Africa, yet beat within the hearts of black men and women wherever they might be. ${ }^{53}$ These soft brushstrokes of racial difference were given less cautious formulation in the writings of sympathetic white progressives like the famous art collector Alfred Barnes, who claimed that not only were African Americans 'primitive', 'natural', 'naive', 'spontaneous', and 'untutored' but also 'poet[s] by birth' in 'harmony with nature' who bore within their bodies 'tremendous emotional endowment[s]' and 'luxuriant ... imagination[s]'. ${ }^{54}$

These and other claims to racial distinctiveness that Harlem writers and artists made in the post-war years cut against the grain of the more standard universalist ones that had long underlain progressive politics in the western world. Their writings marked in this sense an important break with earlier conceptions of the relationship between race and nation that circulated in the United States. The nature of that legacy was, however, something of a double-edged sword.

By underscoring the importance of a racial essence that transcended the bounds of the state, the New Negro narrative left an ambivalent legacy. On the one hand, it carved out a realm of symbolic autonomy for black Americans and contributed to the development of an empowering pan-African identity, but it did so, on the other hand, by reinforcing

51 Locke, 'Enter the new negro', p. 634.

52 W. A. Domingo, 'The tropics in New York', and C. McKay, 'The tropics in New York', Survey Graphic, March 1925, pp. 648-50.

53 Cullen, 'Heritage'; and Hughes, 'Poems', pp. 674-5.

54 Barnes, 'Negro art in America', Survey Graphic, March 1925, pp. 668-70. 
the type of racialism that progressives, black and white, had for years set out to question. The fact is that claims to racial difference could, and quickly did, reify into the sort of racial stereotyping which peoples of African descent had long struggled to overcome. Writers like Locke who chose not to repudiate the pernicious idea of race itself, because that strategy seemed hopelessly unrealistic in early twentieth-century America, ultimately knew that imagining a national community wherein race remained the marker of difference among peoples and nation the mark of their identity with one another was a precariously fine line to be drawing.

The version of renaissance that Locke and other New Negro advocates espoused thus took on a notably different shape from the two cases previously examined. Its rescripting of the narrative of race and nation reflected the segregated society and demographic realities in which it took shape. The hostile racial climate of post-war America and a long history of segregation militated not only against the type of racial intermixture that was common in Latin America but even against the sort of symbolic syncretic ideals that might have produced an American version of la raza cosmica. Moreover, the demographic realities that black Americans faced as a minority group in the United States and the circumstances under which many of their ancestors had come to North America did not point very neatly toward the founding of anything like a post-colonial nation-state as in the Irish case.

The New Negro narrative might thus be viewed as something of a political compromise in a war of positioning, as a delicately balanced pluralist ideal that rescripted the symbolic infrastructure of racial discourse in the United States and the western world without threatening the dominant racial imaginary too completely. In this sense, the New Negro narrative can be understood as a bid to gain for peoples of African descent an increased mobility within the realm of symbols from that which was offered by the dominant discourses of race and nation, while the narrative it proposed was, as importantly, a careful redefinition of the relationship between race and nation that did not challenge in any fundamental way the prevailing idea in America that the races of the world were, indeed, essentially different.

\section{Conclusion: the Harlem Renaissance in global perspective}

This essay proposed at the start that situating the Harlem Renaissance alongside the Irish and Mexican Renaissances would lead to new insights. Let us leave off with two. First, we have seen that these renaissances shared a common discursive concern with the equation of race and nation while reflecting unique national circumstances. In Ireland, a subaltern renaissance drew hard racial lines between the colonizer and colonized in an effort to justify the rights of Irishmen to their own nation-state. In Mexico, a state-sponsored renaissance propagated a syncretic national identity in which the colonizer and colonized merged at least theoretically into a single mestizo race. And the Harlem Renaissance proposed a pluralist national community in which the races, transnational in origin, were counterposed by a civic nationalism that bound the races to one another culturally and politically within the bounds of the nation-state. 
Second, we have seen that each of these renaissances took part in a larger transnational dialogue that we might choose to label 'progressive'. Not only did each partake in a direct conversation with progressives abroad, but each was also discursively structured both in response to a dominant western racial ideology that devalued non-Anglo-Saxon peoples and by a burgeoning new pluralist discourse in the international progressive community. The Irish case, as we have seen, imagined a glorious Celtic race as an alternative to a homogenized British identity, and its nationalists imagined a global order that had room on its stage for a minor post-colonial nation like Ireland to play its part in world affairs without being subjected to the strictures of colonizing empires like that of Britain. The Mexican case, for its part, challenged prevailing western ideas of racial evolution by situating the mestizo at the forefront of human evolution and claiming that a nation like itself had global significance precisely because it prophesied the breakdown of the modern racial order. And the Harlem case put forward a pluralist model for social organization that not only denounced the standards by which one could rank races and nations in the first place but imagined a national and world order that celebrated racial difference by placing subaltern peoples at the symbolic centre rather than margins of modern history.

Bob Johnson is an Assistant Professor of History at the New College of Florida. 